\title{
EFFECT OF MODIFIED MANUFACTURING PROCEDURE ON THE OVERALL QUALITY ATTRIBUTES AND SAFETY OF KISHK
}

\author{
Elham Hajj*1, Hussein Dib², Rita Yaacoub², Oula Mohyeddin², Mayssa Al-Amin² \\ and Zeynab Mcheik ${ }^{2}$ \\ ${ }^{1}$ Department of Animal Sciences, Faculty of Agricultural Engineering and Veterinary \\ Medicine, Lebanese University, Dekwaneh, Mount-Lebanon \\ ${ }^{2}$ Department of Food Technology, Faculty of Agricultural Engineering and Veterinary \\ Medicine, Lebanese University, Dekwaneh, Mount-Lebanon \\ *Correspondence: Elham Hajj \\ elhamhajj@hotmail.com
}

(Received July 2018 - Accepted May 2019)

\begin{abstract}
Hajj, E. Dib, H. Yaacoub, R. Mohyeddin, O. Al-Amin, M. and Mcheik, Z. 2019. Effect of modified manufacturing procedure on the overall quality attributes and safety of Kishk. Lebanese Science Journal. 20(2): 215-229.

The traditional manufacturing method of Kishk involves a daily addition of plain yoghurt to Bourghul (5:1 ratio), followed by heavy handling during the 5-day period of uncontrolled fermentation. In order to improve quality, safety and yield losses, a modified procedure with a single addition of strained yoghurt (Labneh), in a 3:1 ratio, was investigated. The physico-chemical, microbiological and sensory characteristics of both Kishk products were assessed during five days of controlled fermentation (RT: 23$25{ }^{\circ} \mathrm{C}$; RH: >85\%). Green and dried modified-Kishk were of similar quality characteristics when compared to traditional ones. Moisture content was lower in traditional (63\%) compared to modified (66\%), whereas titratable acidity was higher in modified Kishk (1.22 against $1.02 \%)$. Peroxidation $(P V=0 ; T B A R S=0.2 \mathrm{mg}$ $M D A / K g$ ), and lipolysis (AV $\max 3.48 \%$ ) were always in the acceptable ranges. Pathogenic bacteria (E. coli, Salmonella spp., L. monocytogenes, S. aureus) were not detected neither in green nor in dried Kishk. Sensory analysis revealed a harder texture, higher viscosity and higher scores for appearance, odor and overall acceptability in green Modified-Kishk. After drying into fine powder, Modified-Kishk showed improved nutritional, organoleptic and physical quality attributes. The modified end-product can conveniently be safely produced on an industrial scale with optimum conditions.
\end{abstract}

http://dx.doi.org/10.22453/LSJ-020.2.215-229 
Key Words: Kishk manufacture, Physic-chemical, Microbiology, Sensory, Powder, Rehydration.

\section{INTRODUCTION}

Kishk, a fermented dairy-wheat product, is an important part of diets of many people in Asia with around 4000 MT production per year in Lebanon (Dib, 2017, unpublished data). Because of its keeping quality under ambient conditions and high nutritional value (Tamime et al. 1997), Kishk is still a major home food strategic reserve (Mouneh) and effectively contributes to family food security. This product may preserve milk protein from spoilage, increase its nutritional value and improve its sensory properties (Abou Zeid, 2016).

Traditionally, Kishk is made out of Bourghol (parboiled cracked durum wheat) and plain yoghurt (Laban). The mixture is left to ferment at ambient temperature (23-25 ${ }^{\circ} \mathrm{C}$ ) for several days (3 to 8 days) and then sun-dried to $6-12 \%$ moisture content. The amount of plain yoghurt added depends upon the pre-mix absorption rate which is governed by the fermentation pace as affected by ambient temperature, relative humidity (RH), culture and moisture content. The end product may be then milled into fine powder or left in its original coarse state. The process includes progressive addition and mixing of yoghurt on a daily basis. The necessary frequent and heavy handling of Kishk during processing may threaten the safety of the end product. Toxins produced by Bacillus cereus were reported by Tamime and McNulty (1999). In addition, the uncontrolled fermentation, fluctuation of incubation temperature and relative humidity may lead to inferior quality end product. However, the low moisture content $(<10 \%)$, the acidic nature $(\mathrm{pH} \sim 3.8)$ and the addition of salt during the manufacture may ensure the relative safety of Kishk (Tamime et al. 1997, 1999 and 2000).

Recently, rheological and functional properties of Kishk powders, such as particle size distribution and flowing properties, have been studied and found to be affected by the cereal/yoghurt ratio, the ingredients' composition, the manufacturing process and drying technique (Salameh et al. 2016). This research was designed to modify the traditional manufacturing procedure of Kishk by replacing the daily addition of plain yoghurt with one batch addition of strained yoghurt (Labneh). The aim was to limit the handling in traditional preparation of Kishk and to facilitate its commercial industrialization while maintaining its hygienic requirements and quality attributes. Therefore, the specific objectives were to monitor the changes in physico-chemical, microbiological and sensory attributes of kishk occurring as a result of manufacturing procedure modification.

\section{MATERIAL AND METHODS}

\section{Kishk production}

According to the traditional method (Trad-Kishk), white extra-coarse Bourghol was washed, dried, and then mixed with yoghurt -Laban- (87\% moisture) made from 
whole goat's milk (provided by local producer). The premix (1:1 ratio) was left at room temperature $\left(23-25^{\circ} \mathrm{C}\right.$ ) for 12 hours before kneading it using meat mincer (Figure 1). Plain yoghurt was added daily for four more days, giving a final ratio of Bourghol: Laban equal 1:5. The modified process (Mod-Kishk) included the addition of all the required dairy solids to the premix on day one, in the form of strained goat yoghurt or Labneh (50\% moisture, provided by local producer) to a final ratio of 1:3 (Bourghol: Labneh). The resulting dough was thoroughly mixed and kneaded, salted (3\%) and left at ambient temperature $\left(23-25{ }^{\circ} \mathrm{C}\right)$ and $\mathrm{RH}$ of $>85 \%$ for fermentation in a stainless steel container covered with a mesh (Figure 1). Prior to milling into fine powder, drying was carried out indoors in open air for 10 days. The end products were then packed in air-tight glass jars and held at refrigeration temperature for analyses.

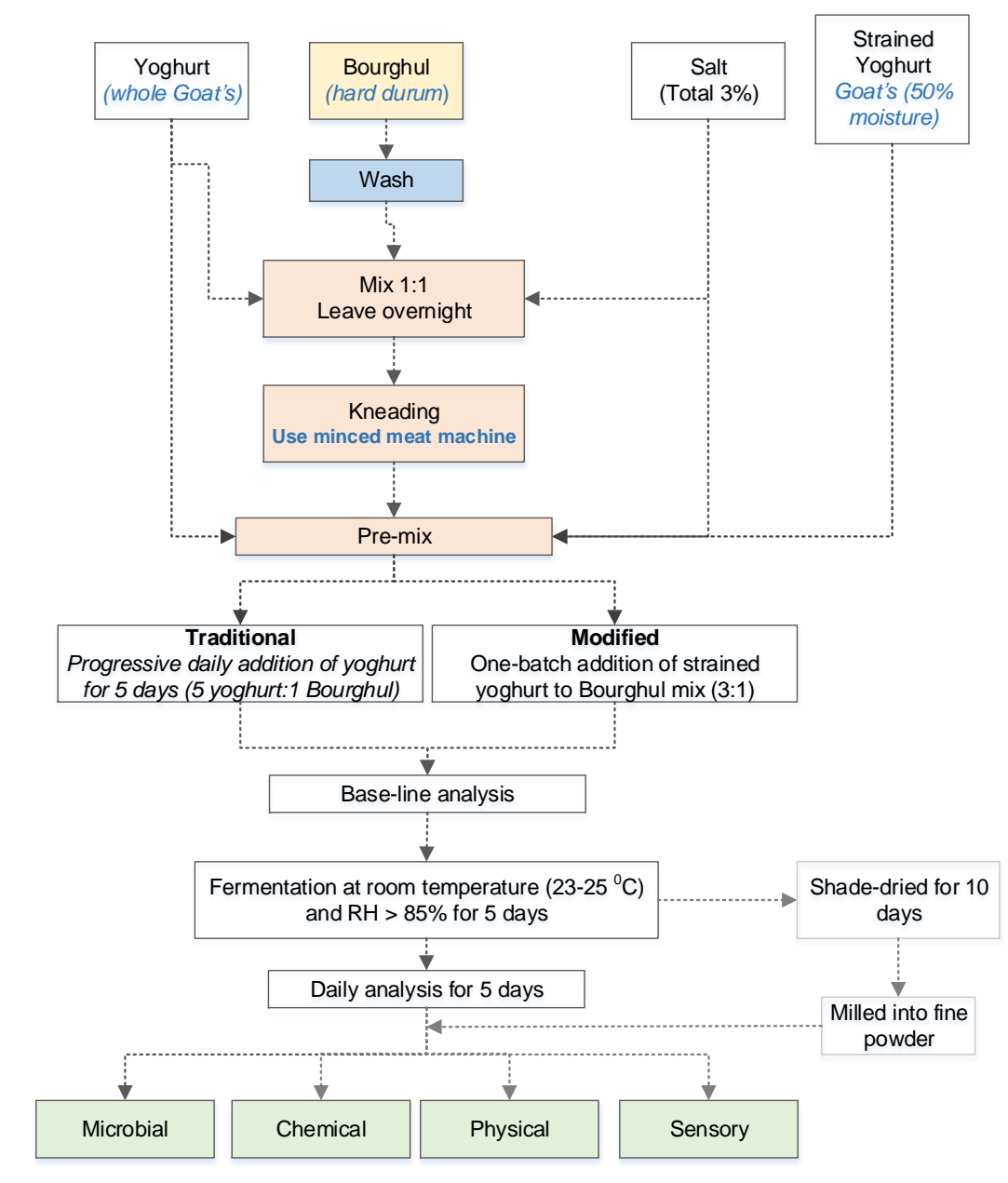

Figure 1. Summary of the steps taken during the Kishk manufacturing of the traditional and modified types and analysis.

\section{Chemical and physical analysis}

Samples of green Kishk (moist) were taken 12 hours after the preparation of the premix and then, every morning for the 5-day period of fermentation. For dry Kishk, 
samples were taken directly from the refrigerated jars as required. Batches for both procedures were repeated three times.

Moisture content was determined using the oven method according to AOAC (1996). Water activity (Aw) was measured using a water activity meter (HYGROPALM Retronic, 60830142). Determination of total and soluble nitrogen (TN, SN) contents was performed using Kjeldahl method (Jones, 1991) and multiplied by 6.26 to calculate protein content. This conversion factor is derived from those for dairy (6.38) and cereals (5.7), on the basis of the used cereal to dairy ratio.

Fat content was determined according to the Van Gulik method (ISO 3432, 2008), and fat extraction using the Bligh \& Dyer (1959) method. Acid value of the extracted fat was determined as described by ISO 660 (1983), whereas peroxide value was adapted from that of Al-Fatlawi and Abbas (2010). Thiobarbituric Acid Reactive Substances (TBARS) values were determined using the method described by Bostoglou et al. (1994). Titratable acidity (TA) was performed according to the AOAC (1996) and salt content according to Ronald \& Ronal (1991).

For green Kishk, the determination of coarseness was performed according to Tuohy (1989). The hardness of the product was performed using a penetrometer of Setamatic Stanhope Seta Prolabo 17500-0 equipped with a cylindrical probe of $3.5 \mathrm{~cm}$ diameter and $7.5 \mathrm{~cm}$ length. Solubility Index for green and dry Kishk were determined as described by the American Dry Milk Institute (ADMI, 1971). To measure the viscosity, a known mass of green Kishk was dissolved in water $(1: 2 \mathrm{w}: \mathrm{v})$ and heated until boiling, then cooled in ice water until analysis. Kishk soup was obtained by dissolving a mass $(10 \%)$ in potable water, boiling it for 5 minutes and then cooling it down to $20{ }^{\circ} \mathrm{C}$. Viscosity was determined using a Brookfield Digital Viscometer (dyn $\left.\mathrm{cm}^{-1}\right)$, whereas density was determined using densitometer $\left(\mathrm{g} \mathrm{dm}^{-3}\right)$ at $20{ }^{\circ} \mathrm{C}$. Dispersibility (Tuohy 1989), sinkability (Schober \& Fitzpatrick 2005) and wettability (Fäldt \& Bergenståhl 1996) of dry Kishk/ were adapted from those of milk powders.

\section{Microbiological analysis}

For pre-enrichment, $25 \mathrm{~g}$ of Kishk sample were weighed into a sterile bag and then put into $225 \mathrm{~mL}$ of buffer Ed peptone water. The mixture was homogenized using a Stomacher for 5 minutes, and then incubated at room temperature for $15 \mathrm{~min}$. After homogenization, aliquots of samples were serially diluted, then diluents were spreadplated onto specific agars for the detection and enumeration. These included total aerobic count (ISO 4833-2:2013), total coliforms (ISO 4832:2006), E. coli (ISO 166492: 2001), Salmonella spp. (ISO 6579:2002/Cor 1:2004), Listeria monocytogenes (ISO 11290-1:1996), sulfite reducing anaerobic bacteria (ISO 15213:2003) and Staphylococcus aureus (ISO 6888-1: 1999). Similarly, Lactic Acid Bacteria were grown on MRS agar and enumerated according to ISO (ISO 15214:1998). 


\section{Sensory analysis}

For the sensory assessment of Kishk, green kishk samples were obtained directly after the fermentation. Dried samples $(10 \mathrm{~g})$ were reconstituted in potable water (100 $\mathrm{ml})$ and boiled for 5 minutes. The soup was cooled down to taste $\left(45-50{ }^{\circ} \mathrm{C}\right)$. Sensory descriptive analysis of both green and reconstituted dry Kishk (soup) was performed using the profiling method (BS ISO 13299:2003). Sensory attributes were assessed by nine trained panelists ( 8 women and 1 man, aged between 30 and 50 years old). Descriptors were selected by a mixed procedure involving literature review and descriptors generation sessions by the panelists. Samples were rated for the intensity of color, odor, flavor, texture and taste attributes as well as overall acceptability on a 9point structured interval scale, where point " 1 " represented a low intensity and point " 9 " represented a high intensity for each characteristic. The references chosen for the point 1 then 9 of each attribute were evaluated before tasting and scoring the sample. A total of 14 and 17 sensory attributes were selected for analysis of green and reconstituted kishk respectively.

Hedonic tests were carried out on 50 consumers who rated their acceptability (overall, appearance, odor, texture and taste) on a 7-point hedonic scale ranging from extremely dislike (score 1) to extremely like (score 7).

The sample preparation and presentation were the same for all tested samples of each product. $50 \mathrm{~g}$ of green kishk or $50 \mathrm{ml}$ of kishk soup were served in plastic plates or cups respectively, identified by a three digit code number and mineral water was used as palate cleanser.

\section{Data analysis}

Student's t-test, analysis of variance (two-way repeated measures ANOVA) and Bonferroni t-test for multiple comparisons of means were performed using SigmaStat (Jandel Scientific). For sensory data, the sources of variation were the samples and the panelists for each sensory descriptor. Principal component analysis (PCA) based on Pearson was performed on the physico-chemical data using XLSTAT 2014.5.03 (Addinsoft, NY, USA), in order to describe the main variation and illustrate the relationship among samples and variables.

\section{RESULTS AND DISCUSSION}

Fermented dairy products are subject to a matrix of variables that control their development. These include moisture content; hence water activity, temperature and time of fermentation, and the fermenting microflora. For Kishk, the matrix is further complicated through the inclusion of Bourghol in the fermented product. 


\section{Changes during the fermentation process}

Moisture content was significantly higher in Trad-Kishk than in modified one $(\mathrm{p}<0.05)$, due to the daily consecutive addition of plain yoghurt (Table 1). The final Trad-Kishk gained 30\% moisture, as compared to the initial product, against $24 \%$ for the Mod-Kishk. Due to the gradual hydration of Bourghol, both types of Kishk showed a significant increase in water activity, as a result of moisture increase. Titratable acidity increased, from $0.27 \%$, in the common premix, to a maximum level of $1.26 \%$ in ModKishk by day 4 (Table 1). This significant increase in acidity, was mainly due to the addition of all required Labneh on day 1 i.e. larger amount of lactic culture. During the fermentation stage, lactic and other organic acids such as acetic acid (Tamime et al. 1999) were formed, causing a decrease in the $\mathrm{pH}$, with a simultaneous increase in acidity. The length of the conditioning period influenced the "acid" character of Kishk (Tamime et al., 2000); which is particularly appreciated by consumers. For this, many Kishk producers extend on purpose the fermentation period. In addition to the flavor, the organic acids produced during fermentation exhibit inhibitory activities against a wide range of pathogens (Salama et al. 1992), thereby enhancing the safety of the end product.

Protein changes were not different between both types during the fermentation period (Table 1). Trad-Kishk exhibited a gradual increase in fat content, due to the daily addition of whole fat yoghurt, at $3.9 \%$ fat (Table 1); however, this trend was not found significant after three days of fermentation $(\mathrm{P}>0.05)$. Acid value, used as an assessment of hydrolysis development of fat, was higher in Trad-Kishk (3.5\%) than in Mod-Kishk (1.5\%) (Table 1). This could be due to the higher moisture of Trad-Kishk through the daily addition of yoghurt, which may enhance fat hydrolysis. On the other hand, no development of peroxide value was observed during the fermentation period, in both Kishk products. Similarly, TBARS as an estimation of secondary lipid oxidation products, were not detected in green products, except for a non-significant level on the $4^{\text {th }}$ and $5^{\text {th }}$ days in Trad-Kishk $(0.16 \pm 0.23$ and $0.20 \pm 0.02 \mathrm{mg}$ MDA equiv/kg). This suggests that the onset of lipid autoxidation, reflected in both primary and secondary oxidation products levels, did not occur in green Kishk under laboratory conditions. 
Table 1. Chemical characteristics of traditional (T) and modified (M) green Kishk during the 5 days of fermentation period.

\begin{tabular}{|c|c|c|c|c|c|c|}
\hline & \multicolumn{6}{|c|}{ Days } \\
\hline & $\mathbf{0}$ & 1 & 2 & 3 & 4 & 5 \\
\hline \multicolumn{7}{|c|}{ Moisture content (\%) } \\
\hline $\mathrm{T}$ & $\begin{array}{l}50.9^{\mathrm{aA}} \\
(0.79)\end{array}$ & $\begin{array}{c}67.4^{\mathrm{bcA}} \\
(0.10)\end{array}$ & $\begin{array}{c}68.5^{\text {bcA }} \\
(0.99)\end{array}$ & $\begin{array}{c}65.4^{\mathrm{bcA}} \\
(0.28)\end{array}$ & $\begin{array}{l}66.0^{\mathrm{cA}} \\
(1.70)\end{array}$ & $\begin{array}{l}66.3^{\mathrm{cA}} \\
(1.56)\end{array}$ \\
\hline $\mathrm{M}$ & $\begin{array}{l}50.9^{\mathrm{a} A} \\
(0.79)\end{array}$ & $\begin{array}{c}62.2^{\mathrm{bcB}} \\
(1.13)\end{array}$ & $\begin{array}{c}64.4^{\mathrm{bcB}} \\
(1.70)\end{array}$ & $\begin{array}{c}63.6^{\mathrm{bcB}} \\
(0.85)\end{array}$ & $\begin{array}{l}60.6^{\mathrm{cB}} \\
(0.64)\end{array}$ & $\begin{array}{l}63.1^{\mathrm{cB}} \\
(0.71)\end{array}$ \\
\hline \multicolumn{7}{|c|}{ Water activity (Aw) } \\
\hline $\mathrm{T}$ & $\begin{array}{l}0.936^{\mathrm{aA}} \\
(0.001)\end{array}$ & $\begin{array}{l}0.949^{\mathrm{bA}} \\
(0.012)\end{array}$ & $\begin{array}{l}0.947^{\mathrm{A}} \\
(0.006)\end{array}$ & $\begin{array}{l}0.948^{\mathrm{bA}} \\
(0.005)\end{array}$ & $\begin{array}{l}0.962^{\mathrm{eA}} \\
(0.003)\end{array}$ & $\begin{array}{l}0.956^{\mathrm{fA}} \\
(0.002)\end{array}$ \\
\hline $\mathrm{M}$ & $\begin{array}{l}0.936^{\mathrm{aA}} \\
(0.001)\end{array}$ & $\begin{array}{l}0.935^{\mathrm{bB}} \\
(0.006)\end{array}$ & $\begin{array}{l}0.946^{\mathrm{cB}} \\
(0.002)\end{array}$ & $\begin{array}{l}0.946^{\mathrm{cB}} \\
(0.004)\end{array}$ & $\begin{array}{l}0.917^{\mathrm{dB}} \\
(0.023)\end{array}$ & $\begin{array}{l}0.944^{\mathrm{eB}} \\
(0.001)\end{array}$ \\
\hline \multicolumn{7}{|c|}{ Titratable acidity (\%) } \\
\hline $\mathrm{T}$ & $\begin{array}{l}0.27^{\mathrm{aA}} \\
(0.02)\end{array}$ & $\begin{array}{l}0.74^{\mathrm{bA}} \\
(0.03)\end{array}$ & $\begin{array}{l}0.72^{\mathrm{bA}} \\
(0.00)\end{array}$ & $\begin{array}{l}0.88^{\mathrm{cA}} \\
(0.04)\end{array}$ & $\begin{array}{l}1.04^{\mathrm{dA}} \\
(0.06)\end{array}$ & $\begin{array}{l}1.02^{\mathrm{dA}} \\
(0.00)\end{array}$ \\
\hline $\mathrm{M}$ & $\begin{array}{l}0.27^{\mathrm{a} A} \\
(0.02)\end{array}$ & $\begin{array}{l}1.17^{\mathrm{bB}} \\
(0.00)\end{array}$ & $\begin{array}{l}1.13^{\mathrm{bB}} \\
(0.00)\end{array}$ & $\begin{array}{l}1.24^{\mathrm{bB}} \\
(0.03)\end{array}$ & $\begin{array}{l}1.26^{\mathrm{cB}} \\
(0.03)\end{array}$ & $\begin{array}{l}1.22^{\mathrm{dB}} \\
(0.00)\end{array}$ \\
\hline \multicolumn{7}{|c|}{ Protein content $(\%)$} \\
\hline $\mathrm{T}$ & $\begin{array}{l}5.82^{\mathrm{aA}} \\
(0.23)\end{array}$ & $\begin{array}{l}6.04^{\mathrm{aA}} \\
(0.08)\end{array}$ & $\begin{array}{l}6.60^{\mathrm{aA}} \\
(0.84)\end{array}$ & $\begin{array}{l}5.87^{\mathrm{aA}} \\
(0.40)\end{array}$ & $\begin{array}{l}5.45^{\mathrm{aA}} \\
(0.31)\end{array}$ & $\begin{array}{l}5.79^{\mathrm{aA}} \\
(0.05)\end{array}$ \\
\hline $\mathrm{M}$ & $\begin{array}{l}7.82^{\mathrm{a} A} \\
(0.23)\end{array}$ & $\begin{array}{l}6.17^{\mathrm{a} A} \\
(0.18)\end{array}$ & $\begin{array}{l}6.34^{\mathrm{aA}} \\
(0.67)\end{array}$ & $\begin{array}{l}5.95^{\mathrm{aA}} \\
(1.08)\end{array}$ & $\begin{array}{l}6.12^{\mathrm{a} A} \\
(0.81)\end{array}$ & $\begin{array}{l}6.25^{\mathrm{aA}} \\
(0.07)\end{array}$ \\
\hline \multicolumn{7}{|c|}{ Fat content $(\%)$} \\
\hline $\mathrm{T}$ & $\begin{array}{l}1.85^{\mathrm{aA}} \\
(0.02)\end{array}$ & $\begin{array}{c}2.65^{\mathrm{abA}} \\
(0.00)\end{array}$ & $\begin{array}{l}3.52^{\mathrm{bA}} \\
(0.11)\end{array}$ & $\begin{array}{l}4.7^{\mathrm{cA}} \\
(0.07)\end{array}$ & $\begin{array}{l}4.59^{\mathrm{cA}} \\
(0.05)\end{array}$ & $\begin{array}{l}5.42^{\mathrm{cA}} \\
(0.08)\end{array}$ \\
\hline $\mathrm{M}$ & $\begin{array}{l}1.58^{\mathrm{a} A} \\
(0.03)\end{array}$ & $\begin{array}{c}8.0^{\mathrm{bB}} \\
(0.21)\end{array}$ & $\begin{array}{l}8.62^{\mathrm{bB}} \\
(0.24)\end{array}$ & $\begin{array}{l}7.87^{\mathrm{bB}} \\
(0.35)\end{array}$ & $\begin{array}{l}8.45^{\mathrm{bB}} \\
(0.40)\end{array}$ & $\begin{array}{l}8.43^{\mathrm{bB}} \\
(0.24)\end{array}$ \\
\hline \multicolumn{7}{|c|}{ Acid Value (\%) } \\
\hline $\mathrm{T}$ & $\begin{array}{l}2.82^{\mathrm{aA}} \\
(0.05)\end{array}$ & $\begin{array}{l}3.48^{\mathrm{bA}} \\
(0.07)\end{array}$ & $\begin{array}{l}2.17^{\mathrm{cA}} \\
(0.11)\end{array}$ & $\begin{array}{l}2.06^{\mathrm{cA}} \\
(0.11)\end{array}$ & $\begin{array}{l}2.98^{\mathrm{dA}} \\
(0.14)\end{array}$ & $\begin{array}{l}3.09^{\mathrm{dA}} \\
(0.06)\end{array}$ \\
\hline $\mathrm{M}$ & $\begin{array}{l}2.82^{\mathrm{aA}} \\
(0.05)\end{array}$ & $\begin{array}{l}1.45^{\mathrm{bB}} \\
(0.28)\end{array}$ & $\begin{array}{l}2.44^{\mathrm{cA}} \\
(0.25)\end{array}$ & $\begin{array}{l}2.48^{\mathrm{cB}} \\
(0.08)\end{array}$ & $\begin{array}{l}2.14^{\mathrm{cB}} \\
(0.07)\end{array}$ & $\begin{array}{l}2.68^{\mathrm{dB}} \\
(0.20)\end{array}$ \\
\hline
\end{tabular}

Values with different small and capital letters within a row and a column respectively are significantly different at the 5\% level (two-way repeated measures ANOVABonferroni t-test).

For the physical characteristics, the solubility index of Trad-Kishk showed higher values than Mod-Kishk, only during the fermentation process (Table 2). Coarseness and density were also significantly higher in Trad-Kishk in comparison to Mod-Kishk (Table 2). Hardness was always significantly lower in Trad-Kishk, due to the consecutive addition of plain yoghurt (Table 2). In both types, body hardness increased significantly during fermentation (Table 2). 
Table 2. Physical characteristics of traditional (T) and modified (M) green Kishk during the 5 days of fermentation period.

\begin{tabular}{|c|c|c|c|c|c|c|}
\hline & \multicolumn{6}{|c|}{ Days } \\
\hline & 0 & $\mathbf{1}$ & 2 & 3 & 4 & 5 \\
\hline \multicolumn{7}{|c|}{ Solubility index (\%) } \\
\hline $\mathrm{T}$ & $\begin{array}{c}64.69^{\mathrm{aA}} \\
(0.57)\end{array}$ & $\begin{array}{c}66.84^{\mathrm{aA}} \\
(1.33)\end{array}$ & $\begin{array}{l}74.6^{\mathrm{bA}} \\
(1.06)\end{array}$ & $\begin{array}{c}76.17^{\mathrm{bA}} \\
(1.73)\end{array}$ & $\begin{array}{c}76.05^{\mathrm{bA}} \\
(1.16)\end{array}$ & $\begin{array}{c}70.86^{\mathrm{cA}} \\
(1.87)\end{array}$ \\
\hline M & $\begin{array}{c}64.69^{\mathrm{aA}} \\
(0.57)\end{array}$ & $\begin{array}{c}72.50^{\mathrm{bB}} \\
(1.70)\end{array}$ & $\begin{array}{c}70.05^{\mathrm{bB}} \\
(1.95)\end{array}$ & $\begin{array}{c}70.91^{\mathrm{bB}} \\
(1.87)\end{array}$ & $\begin{array}{c}75.12^{\mathrm{bA}} \\
(1.33)\end{array}$ & $\begin{array}{c}69.84^{\mathrm{cA}} \\
(0.86)\end{array}$ \\
\hline \multicolumn{7}{|c|}{ Coarseness (g) } \\
\hline $\mathrm{T}$ & $\begin{array}{l}1.62^{\mathrm{abA}} \\
(0.01)\end{array}$ & $\begin{array}{c}1.54^{\mathrm{abA}} \\
(0.01)\end{array}$ & $\begin{array}{c}1.39^{\mathrm{abA}} \\
(0.16)\end{array}$ & $\begin{array}{l}1.31^{\mathrm{bcA}} \\
(0.01)\end{array}$ & $\begin{array}{c}1.44^{\mathrm{bcA}} \\
(0.01)\end{array}$ & $\begin{array}{c}1.61^{\mathrm{bdA}} \\
(0.03)\end{array}$ \\
\hline $\mathrm{M}$ & $\begin{array}{l}1.62^{\mathrm{a} A} \\
(0.01)\end{array}$ & $\begin{array}{l}1.24^{\mathrm{bB}} \\
(0.06)\end{array}$ & $\begin{array}{l}1.24^{\mathrm{bB}} \\
(0.07)\end{array}$ & $\begin{array}{l}1.27^{\mathrm{bA}} \\
(0.04)\end{array}$ & $\begin{array}{l}1.19^{\mathrm{bB}} \\
(0.13)\end{array}$ & $\begin{array}{l}1.77^{\mathrm{cB}} \\
(0.04)\end{array}$ \\
\hline \multicolumn{7}{|c|}{ Hardness (mm) } \\
\hline $\mathrm{T}$ & $\begin{array}{c}33.50^{\mathrm{aA}} \\
(0.23)\end{array}$ & $\begin{array}{c}30.70^{\mathrm{bA}} \\
(0.14)\end{array}$ & $\begin{array}{c}40.85^{\mathrm{cA}} \\
(0.78)\end{array}$ & $\begin{array}{c}33.35^{\mathrm{dA}} \\
(0.64)\end{array}$ & $\begin{array}{c}29.60^{\mathrm{eA}} \\
(0.28)\end{array}$ & $\begin{array}{c}29.95^{\mathrm{eA}} \\
(0.07)\end{array}$ \\
\hline $\mathrm{M}$ & $\begin{array}{c}33.50^{\mathrm{aA}} \\
(0.23)\end{array}$ & $\begin{array}{c}29.70^{\mathrm{bB}} \\
(0.00)\end{array}$ & $\begin{array}{c}29.80^{\mathrm{bB}} \\
(0.14)\end{array}$ & $\begin{array}{c}29.35^{\mathrm{bB}} \\
(0.07)\end{array}$ & $\begin{array}{c}24.30^{\mathrm{cB}} \\
(0.28)\end{array}$ & $\begin{array}{c}21.20^{\mathrm{dB}} \\
(0.42)\end{array}$ \\
\hline \multicolumn{7}{|c|}{ Density } \\
\hline $\mathrm{T}$ & $\begin{array}{l}1.038^{\mathrm{aA}} \\
(0.003)\end{array}$ & $\begin{array}{l}1.034^{\mathrm{bA}} \\
(0.000)\end{array}$ & $\begin{array}{l}1.037^{\mathrm{cA}} \\
(0.002)\end{array}$ & $\begin{array}{l}1.035^{\mathrm{dA}} \\
(0.000)\end{array}$ & $\begin{array}{l}1.035^{\mathrm{dA}} \\
(0.001)\end{array}$ & $\begin{array}{l}1.035^{\mathrm{eA}} \\
(0.000)\end{array}$ \\
\hline $\mathrm{M}$ & $\begin{array}{l}1.038^{\mathrm{aA}} \\
(0.003)\end{array}$ & $\begin{array}{l}1.035^{\mathrm{bB}} \\
(0.001)\end{array}$ & $\begin{array}{l}1.030^{\mathrm{cB}} \\
(0.004)\end{array}$ & $\begin{array}{l}1.035^{\mathrm{dB}} \\
(0.001)\end{array}$ & $\begin{array}{l}1.032^{\mathrm{eB}} \\
(0.001)\end{array}$ & $\begin{array}{l}1.034^{\mathrm{fB}} \\
(0.000)\end{array}$ \\
\hline
\end{tabular}

Values with different small and capital letters within a row and a column respectively are significantly different at the 5\% level (two-way repeated measures ANOVABonferroni t-test).

When testing for the viscosity, the Trad-Kishk showed a very low shear resistance at 10 and $20 \mathrm{rpm}$ (Figure 2), due to its coarse texture and low amount of dairy on day 1. To the contrary, Mod-Kishk had highest values on day 1, due to the incorporation of all dairy right from the beginning. Closest shear thinning between both products was observed on day 3 . Thereafter, the different speed of rotation showed a similar pattern of viscosity development for both types of Kishk. Traditional and modified green Kishk exhibited pseudo-plastic behavior (shear-thinning) at $20^{\circ} \mathrm{C}$, since their viscosities decreased as the shear rate increased. This was also demonstrated in rheological studies on Tarhana (similar to Kishk, in Turkey), suggesting a pseudoplastic behavior at all temperatures studied (Ibanoglu \& Ibanoglu 1999). 


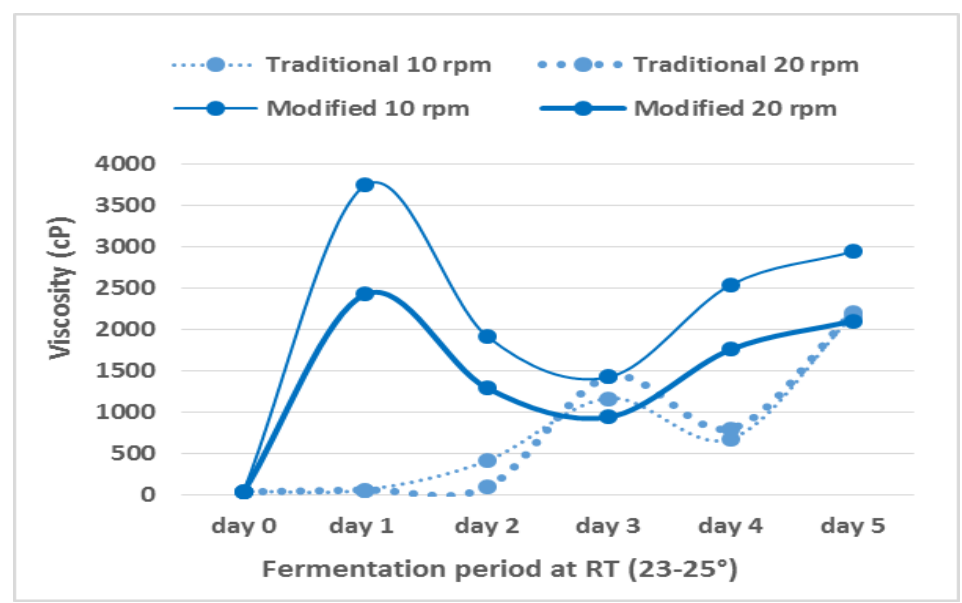

Figure 2. Viscosity development of traditional and modified green Kishk during the 5 days of fermentation.

In order to study the relationship between variables during the fermentation period, principal component analysis (PCA) was carried out on the physicochemical data of green Kishk. The first two of these PCs accounted for 77\% of the variance observed (Figure 3). The solubility and titratable acidity were highly correlated, contributing positively to the PC1, as opposed to the moisture content, softness and coarseness. Samples were clearly separated in two clusters on PC1, with traits (high titratable acidity and solubility) related to Mod-Kishk found within the first cluster, and those (high moisture content, softness and coarseness) linked to Trad-Kishk, within the second. On the second factor, acid value and TBARS were positively correlated and opposed to density and water activity.

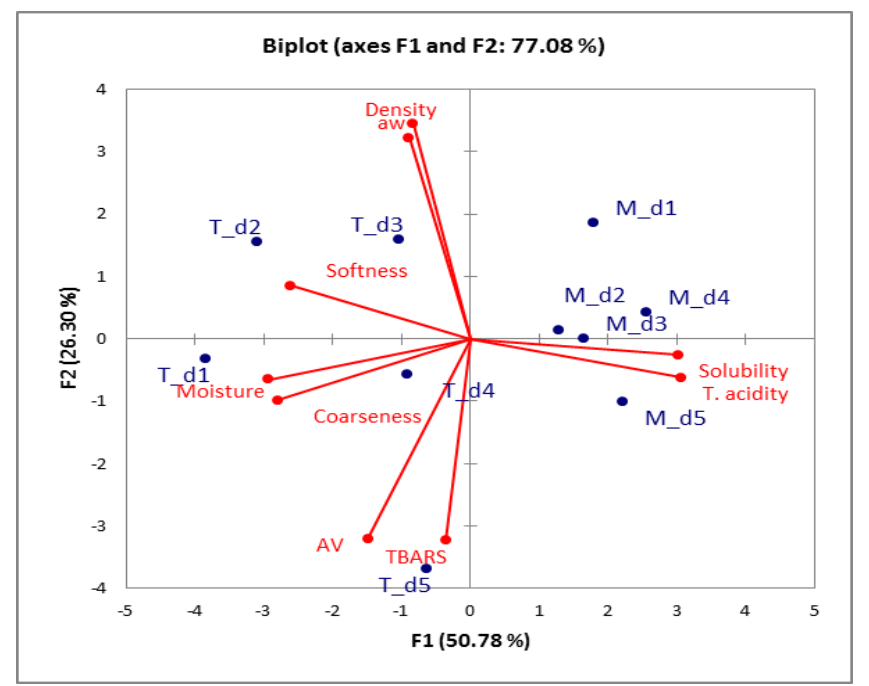

Figure 3. Biplot for factors 1 and 2 of the principal component analysis for the traditional Kishk (T) and modified Kishk (M) sampled on the successive days (d) of the fermentation process. 


\section{Characteristics of dried Kishk}

Clear disparities among physico-chemical characteristics were observed between the final dried products. Despite the same drying conditions, Trad-Kishk retained more moisture $(20.21 \%)$ than the modified one $(16.13 \%)$. Also, water activity values were in agreement with those of moisture content, with 0.81 for Trad-Kishk and 0.79 for ModKishk. This could be linked to the slow hydration process of Bourghul grains, followed by a slow dehydration, in the traditional process. Smaller moisture content (6-13\%) (Tamime et al. 1999; Abou Zeid, 2016; Salameh et al. 2016) and water activity $(<0.7)$ (Tamime \& McNulty, 1999), were reported in the literature, due possibly to longer drying periods. Titratable acidity was $1.38 \%$ for Trad-Kishk against $1.80 \%$ for ModKishk (Table 3), which was consistent with the result reported by Salama et al. (1992) on dry skimmed milk Kishk (1.63\%).

Total proteins were $18.34 \%$ in Trad-Kishk and 20.82\% in Mod-Kishk (Table 3), the equivalent of $22.36 \%$ and $26.09 \%$ on dry Matter Basis (DMB). The difference in proteins content could be linked to the amount of dairy solids added to Bourghol. Also, the higher fat content in Mod-Kishk could be explained by the single addition of strained yoghurt (11.9\% fat), as compared to the use of yoghurt (3.9\% fat) in TradKishk. In addition, the traditional process of daily mixing and kneading may cause some loss of fat as lumps stick on utensils and tools. The fat contents of $16.72 \%$ (Mod-Kishk) and $12.58 \%$ (Trad-Kishk) (Table 3), were higher than a maximum of $11.5 \%$ fat, in commercial Kishk made with 1:4 ratio of Bourghol: plain yoghurt (Tamime et al. 1999). Finally, salt content of Mod-Kishk was slightly higher than that of Trad-kishk. However this difference was not perceptible by sensory panelists.

Table 3. Physicochemical characteristics of traditional and modified dried Kishk.

\begin{tabular}{|c|c|c|}
\hline & Traditional & Modified \\
\hline Moisture content (\%) & $20.21^{\mathrm{a}}(1.45)$ & $16.13^{\mathrm{b}}(0.92)$ \\
\hline Water activity & $0.81^{\mathrm{a}}(0)$ & $0.79^{\mathrm{b}}(0)$ \\
\hline Titratable Acidity (\%) & $1.38^{\mathrm{a}}(0.01)$ & $1.80^{\mathrm{b}}(0.02)$ \\
\hline Protein content $(\%)$ & $18.34^{\mathrm{a}}(0.52)$ & $20.81^{\mathrm{b}}(1.01)$ \\
\hline Fat content $(\%)$ & $12.58^{\mathrm{a}}(0.78)$ & $16.72^{\mathrm{b}}(0.68)$ \\
\hline Acid Value (\%) & $5.62^{\mathrm{a}}(0.02)$ & $1.22^{\mathrm{b}}(0.00)$ \\
\hline Peroxide Value (meq/kg) & $6.82^{\mathrm{a}}(0.72)$ & $2.01^{\mathrm{b}}(0.28)$ \\
\hline TBARS (MDA/Kg) & $0.76^{\mathrm{a}}(0.00)$ & $0.61^{\mathrm{b}}(0.03)$ \\
\hline Dispersibility (sec) & $12.5^{\mathrm{a}}(0.70)$ & $41^{\mathrm{b}}(4.24)$ \\
\hline Sinkability (sec) & $7.5^{\mathrm{a}}(0.70)$ & $9^{b}(1.41)$ \\
\hline Wettability (\%) & $100^{\mathrm{a}}(0.00)$ & $39.78^{\mathrm{b}}(1.39)$ \\
\hline Solubility (\%) & $75.4^{\mathrm{a}}(0.35)$ & $75.03^{\mathrm{a}}(0.56)$ \\
\hline Density & $0.815^{\mathrm{a}}(0.00)$ & $0.790^{\mathrm{b}}(0.00)$ \\
\hline Salt content $(\%)$ & $3.57^{\mathrm{a}}(0.00)$ & $3.77^{\mathrm{b}}(0.02)$ \\
\hline
\end{tabular}

Values between brackets are standard deviations. 
Values with different letters within a row are significantly different at the 5\% level ( $t$ test).

Regarding functional properties, dried Trad-Kishk exhibited better powder rehydration properties reflected in quicker dispersability, sinkability and wettability in water (Table 3). The coarser nature of Trad-Kishk, when compared to the modified one, allowed better water transfer and hydration. The microstructure of Kishk was described as a complex network of macro-constituents (milk protein and wheat starch) embedded in a thick layer of fat, defining key functional properties such as caking, agglomeration and rehydration (Salameh et al., 2016). Thus, the higher level of fat, together with different processing steps of Mod-Kishk, may have imparted different functional properties. Dried Trad-Kishk exhibited higher agglomeration, resulting in better sinkability and wettability. Similar results were described by Murrieta-Pazos et al. (2014) stating that the size of semolina grains increased with water activity and bridges between particles were formed, leading to their agglomeration. Several grains (nuclei) can associate owing to surface rehydration by different physical mechanisms of adhesion and biochemical reactions affecting starch and proteins, explaining the apparent solid bridges between particles. Trad-Kishk exhibited significantly higher density (0.815) than Mod-Kishk (0.790) which may also explain the better sinkability, knowing that agglomerated powders with dense particles normally have the best ability to sink (Bylund, 1995).

\section{Microbiological quality of Kishk}

The evaluation of microbiological composition showed that total viable counts were within the range of $5-6.3 \log _{10} \mathrm{CFU} / \mathrm{g}$, and in line with those $\left(4.64-9.11 \log _{10}\right.$ CFU/g) reported by Tamime et al. (2000). No significant difference in TVC was observed between the two Kishk doughs.

At the beginning of fermentation, the initial count of LAB in the premix was around $4.64 \log _{10} \mathrm{CFU} / \mathrm{g}$ (Figure 4). Brought by the incorporation of fermented milk (yoghurt), these lactic cultures were purely low-acid producing strains of L. bulgaricus and $S$. thermophilus, which were probably dominant due to the nature of the original culture used in the production of yoghurt. In Mod-Kishk, LAB counts increased rapidly to $6.56 \log _{10} \mathrm{CFU} / \mathrm{g}$ within 24 hours of fermentation mostly due to the single addition of strained yoghurt, then decreased markedly after 48 hours of fermentation, mainly due to the increase in acid content and the absence of any additional substrate (yoghurt or strained yoghurt). In Trad-Kishk, LAB counts increased steadily throughout fermentation with the daily incorporation of yoghurt, exhibiting a sharp increase on day 3 (Figure 4) followed by a decrease in LAB counts till the end of fermentation, in a parallel way to Mod-Kishk. The modified process allowed to reach similar LAB counts in a shorter time. Using acidified skimmed milk (Rayeb), Salama et al. (1992) reported a similar manner of development for LAB with much higher counts $\left(6.73-12.68 \log _{10}\right.$ CFU/g). Drying process significantly reduced LAB counts in both products, to $3.2-4.3$ $\log _{10} \mathrm{CFU} / \mathrm{g}$. 


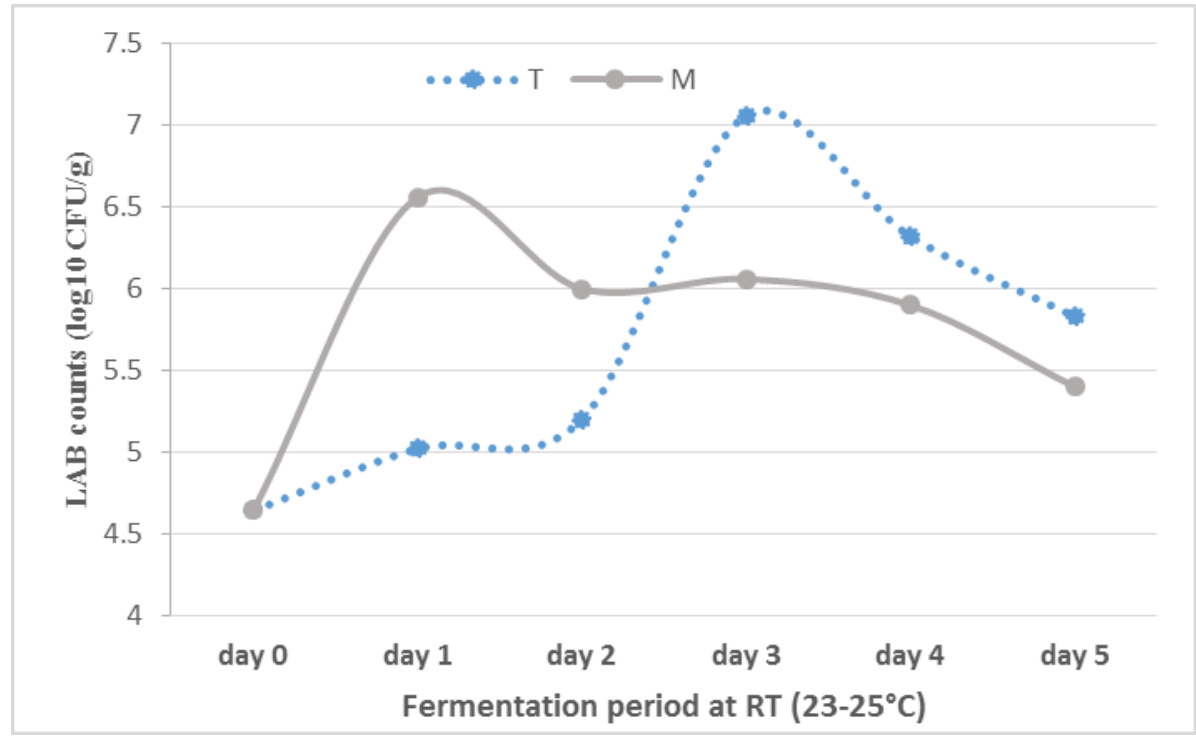

Figure 4. Evolution of Lactic Acid Bacteria $\left(\log _{10} \mathrm{CFU} / \mathrm{g}\right)$ during the 5 days of fermentation in traditional $(\mathrm{T})$ and modified $(\mathrm{M})$ Kishk.

Total coliforms, E. coli, Staphylococcus aureus, Salmonella, Listeria monocytogenes, and anaerobic sulphite reducing bacteria were not detected in any of the dough mixtures, neither in green nor in dried Kishk. The absence of pathogens from our laboratory-made products was due to the strict controlled conditions of manufacture, which might not be the case of commercial products.

\section{Sensory evaluation of Kishk}

Significant differences were observed for color, whereas, no significant differences were observed for lactic odor, stickiness, yoghurt flavor, and graininess in green kishk (Figure 5a). Similar findings regarding color (Toufeili et al. 1999), stickiness, grainy, and slimy characteristics (Tamime et al. 1997) were ascribed to the cereal type and grain characteristics e.g. whole or white meal.

On the other hand, there were no significant differences between the two Kishk soups (Figure 5b) in terms of odor, flavor and taste. However, Trad-Kishk soup was significantly $(\mathrm{P}<0.05)$ darker in color and more sticky, viscous with creamier texture. The high coarseness of Trad-Kishk imparted by Bourghol particles, probably enhanced viscosity and creaminess due to starch gelatinization (Tamime et al. 1997; Toufeili et al. 1999). Limited sensory defects i.e. off-flavor, foreign flavor, bitterness and after-taste were recorded by panelists for both Kishk, in contrast with the results of Muir et al. (2007) reporting high scores for bitterness and cardboard character. 


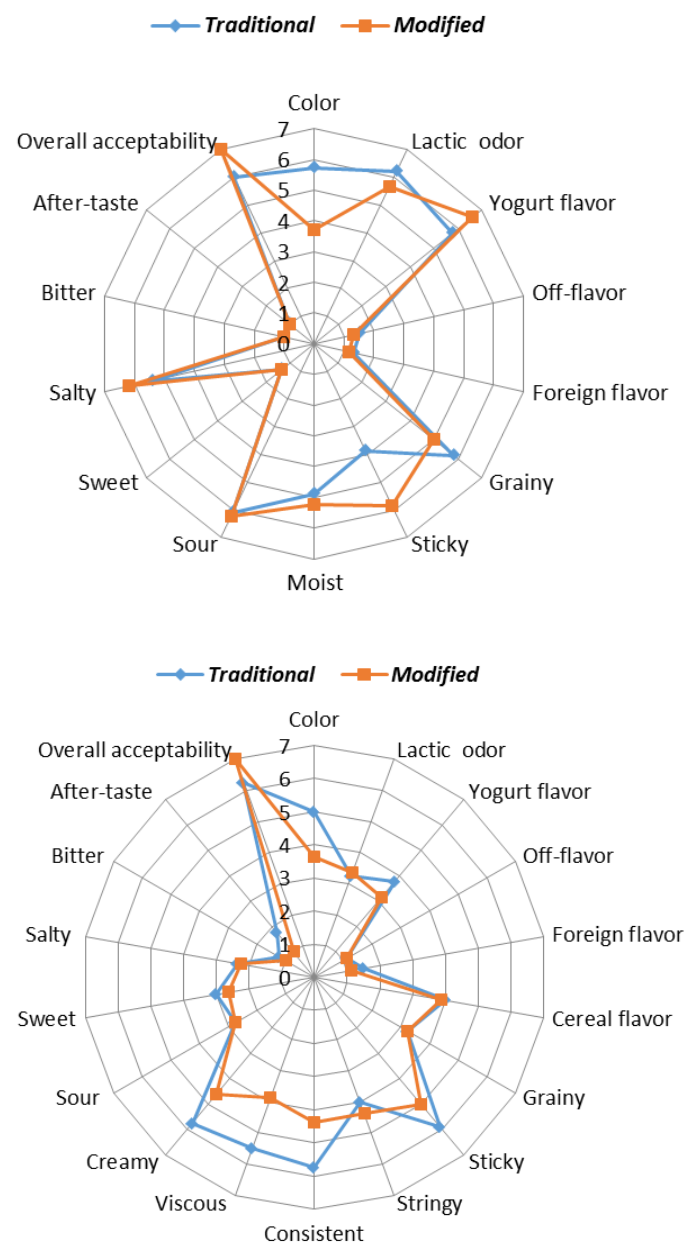

Figure 5. (a) Sensory profiles of green Kishk produced using both traditional and modified methods. (b) Sensory profiles of soups prepared from traditional and modified dried Kishk (Plotted figures are means of 9 panelists' scores).

The panelists exhibited higher acceptability for modified Kishk. This was confirmed by hedonic tests which showed significantly higher overall acceptability by the consumers, as well as in terms of odor and appearance. No significant preference for either product was recorded regarding taste and texture.

\section{CONCLUSION}

The traditional method to produce fermented Kishk was modified by the substitution of the daily addition of plain goat's yoghurt by one batch of strained goat's yoghurt (Labneh $-50 \%$ moisture), and by dehydration of the final product in the shade. The modified addition of all required dairy solids, in the form of strained yoghurt, facilitated the hydration of Bourghol grain, the development of more coherent and softer body, increased solubility index, minimized losses, and improved safety of end product. 
In the Mod-Kishk, the fermentation process and lipolysis slowed down, and to a lesser extent oxidation and formation of off-flavors.

The dried Mod-Kishk had lower moisture content, water activity and lipid deterioration indicators (peroxide value, TBARS and acid value) as compared to the Trad-Kishk. But the modified form presented higher titratable acidity, protein and fat content, suggesting a better nutritional, organoleptic and keeping quality. The addition of all dairy solids in a single step gave a lighter color and higher acceptability of ModKishk. However, the rehydration properties of Kishk powder needs further improvement. This modified end-product could be safely and easily produced on an industrial scale with significant savings in handling.

\section{ACKNOWLEDGMENTS}

Authors gratefully acknowledge the financial support of Lebanese University.

\section{REFERENCES}

Abou Zeid, N.A. 2016. Review of Egyptian cereal-based fermented product (Kishk), International Journal of Agriculture Innovations and Research, 4 (4): 600-609.

Al-Fatlawi, A.L.M. and Abbas, N.M. 2010. Investigating peroxides and acid value in used edible vegetable oils The Iraqi Journal of Agricultural Science, 41 (4): 123-132.

American Dry Milk Institute (ADMI) 1971. Standards for grades of dry milk including methods of analysis, Bulletin 916 (Revised) Chicago: American Dry Milk Institute, Inc

AOAC, 1996. Official Methods of Analysis. $16^{\text {th }}$ ed. Association of Official Analytical Chemists. Washington, DC.

Ardö, Y. and Polychroniadou, A. 1999. Laboratory manual for chemical analysis of cheese. Luxembourg: Office for Official Publications of the European Communities, $123 \mathrm{pp}$.

Bligh, E.G. and Dyer, W.J. 1959. A rapid method of total lipid extraction and Purification. Canadian Journal of Biochemistry and Physiology, 37: 911-917.

Botsoglou, N.A., Fletouris, D.J., Papageorgiou, G.E., Vassilopoulos, V.N., Mantis, A.J. and Trackatellis, A.G. 1994. Rapid, sensitive and specific thiobarbituric acid method for measuring lipid peroxidation in animal tissue, food, and feedstuff samples. Journal of Agricultural and Food Chemistry, 42: 1931-1937.

Bylund, G. 1995. Dairy processing handbook. Tetra Pak Processing Systems AB.

Erbaş, M., Certel, M. and Kemal Uslu, M. 2005. Microbiological and chemical properties of Tarhana during fermentation and storage as wet-sensorial properties of Tarhana soup. LWT - Food Science and Technology, 38: 409-416.

Fäldt, P. and Bergenståhl, B. 1996. Spray-dried whey protein/lactose/soybean oil emulsions. 2. Redispersability, Wettability and particle structure. Food Hydrocolloids, 10: 431-439.

Ibanoglu, S. and Ibanoglu, E. 1999. Rheological properties of cooked tarhana, a cerealbased soup. Food Research International, 32: 29-33. 
Jones, J.B. 1991. Kjeldahl Method for Nitrogen Determination. Athens, Ga: MicroMacro Publishing.

Murrieta-Pazos, I., Gaiani, C., Galet, L., Cuq, B., Desobry, S. and Scher, J. 2011. Comparative study of particle structure evolution during water sorption: Skim and whole milk powders. Colloids and Surfaces B: Biointerfaces, 87: 1-10.

Murrieta-Pazos, I., Galet, L., Patry, S., Gaiani, C. and Scher, J. 2014. Evolution of particle structure during water sorption observed on different size fractions of durum wheat semolina. Powder Technology, 255: 66-73.

Muir, D.D., Tamime, A.Y. and Hunter, E.A. 2007. Sensory properties of Kishk: comparison of products containing bovine and caprine milk. International Journal of Dairy Technology, 48(4): 123 - 127.

Ronald, S.K. and Ronal, S. 1991. Pearson's composition and analysis of food. $9^{\text {th }}$ ed.

Salama, A.A., Damir, A.A. and Safwat, M.M. 1992. Effect of cooking on nutrients, microbial and sensory properties of skimmed milk and Rayeb Kishk. Acta alimentaria, 21: 31-38.

Salameh, C., Scher, J., Petit, J., Gaiani, C., Hosri, C. and Banon, S. 2016. Physicochemical and rheological properties of Lebanese Kishk powder, a dried fermented milk-cereal mixture. Powder Technology, 292: 307-313.

Schober, C. and Fitzpatrick, J.J. 2005. Effect of vortex formation on powder sinkability for reconstituting milk powders in water to high solids content in a stirred tank. Journal of Food Engineering, 71: 1-8.

Tamime, A.Y., Barclay, M.N.I., McNulty, D. and O'Connor, T.P. 1999. Kishk - a dried fermented milk / cereal mixture. 3. Nutritional composition. Lait, 79: 435-448.

Tamime, A.Y. and McNulty, D. 1999. Kishk - a dried fermented milk/cereal mixture. 4. Microbiological quality. Lait, 79: 449-456.

Tamime, A.Y., Muir, D.D., Barclay, M.N.I., Khaskheli, M. and McNulty, D. 1997 (a). Laboratory-made Kishk from wheat, oat and barley. 1. Production and comparison of chemical and nutritional composition of Burghol. Food Research International, 30: 311- 317.

Tamime, A.Y., Muir, D.D., Barclay, M.N.I., Khaskheli, M. and McNulty, D. 1997 (b). Laboratory-made Kishk from wheat, oat and barley. 2. Compositional quality and sensory properties. Food Research International, 30: 319-326.

Tamime, A.Y., Muir, D.D., Khaskheli, M. and Barclay, M.N.I. 2000. Effect of Processing Conditions and Raw Materials on the Properties of Kishk. 1. Compositional and Microbiological Qualities. Lebensmittel-Wissenschaft \& Technologie, 33: 444-451.

Toufeili, I., Melki, C., Shadarevian, S. and Robinson, R.K. 1999. Some nutritional and sensory properties of bulgur and whole wheat meal Kishk (a fermented milkwheat mixture). Food Quality and Preference, 10: 9-15.

Tuohy, J.J. 1989. Some Physical Properties of Milk Powders. Irish Journal of Food Science and Technology, 13: 141-52. 